\title{
Are Indonesian Farmers a Good Manager? A study on Entrepreneurial and Marketing Orientation to Farm Business Performance in Indonesia
}

\author{
Novi Haryati \\ Jurusan Sosial Ekonomi Pertanian/Agribisnis Fakultas Pertanian Universitas Brawijaya \\ e-mail: noviharyati@ub.ac.id
}

\begin{abstract}
Farming is including a business entity because its activities include not only planting on land but also being able to maintain relationships that focus on business interests, such as increased sales and income. As the actor in the business, they are required to be able to have marketing and entrepreneurial skills so that their business performance can be sustainable. The purpose of the research is to understand the relationship between marketing and entrepreneurship to the farming performances, with organization innovation as intervening variables. It is quantitative research and has been conducted in Singosari sub district Malang, Indonesia. Analysis was done by SEM-PLS while 40 farmers were chosen purposively as respondent. The result shows that the Indonesian farmer has basic marketing and entrepreneurship orientation. Both of them has positive and highly significant with the value of 0,41 and 0,53 to farming performance. As an intervening variable, Organizational innovation has positively associated with farmer's performance. Improving the human resources of farmers has been a very important aspect of sustainable business and human resources itself in Agriculture. An experienced and trained farmer will be able to keep working event in an unstable situation.
\end{abstract}

Keywords: Innovation, marketing, entrepreneurial, farming 


\section{INTRODUCTION}

Agriculture has a very strategic role in overall economic development. The contribution of the agricultural sector to the national GDP is (13-14 percent) and absorbs the workforce by 42,61-43,03 million people (2008-2009). The new role of the agricultural sector at this time can be placed within the framework of "3 F contribution in the economy", namely food, feed and fuel (Daryanto, 2009).

Farming is part of the business (Nell \& Napier, 2005; Okello \& Mensah, 2011; Okorley, Acheampong, \& Abenor, 2014). It was shown with the aim of farming is to generate profits and increase sales. Farming business is also including focus on management is demanded to be able to control all uncertainties into a sustainable business (Suess-Reyes \& Fuetsch, 2016; Kallen et al., 2001; Holloway et al. 2006). Farming has several characteristics because it produce agricultural product. Agricultural product application implement with multiple inputs (SuessReyes \& Fuetsch, 2016), after harvesting, farming needs special method and system to communicate agricultural product information to a consumer (Buskop, 2010). Another challenging factors in farming as a business is agribusiness needs a good coordination in supply chain within the actors (Guohua, 2013).

Farming business carried out by farmers in Indonesia is characterized by small capital, small scale land and subsistence farming (Aldillah, 2016). It employs labor from relatives and neighbour (Kasryno, 2016), and thus very lack of competitiveness (Daryanto, 2009). For rice commodities, for example, although to date they still have comparative and competitive advantages, their advantages are getting lower and are vulnerable to external changes in the environment (Daryanto, 2009).

Increasing environmental uncertainty has focused greater attention on firms' overall business orientations, particularly on the marketing orientation and the entrepreneurial orientation(Miles \& Arnold, 1991). Marketing orientation is more than just focusing on customer. It recognizes the concept of consumer sovereignty; and that consumption is not the sole purpose of production, but it also recognizes that a firm is free to pick who its customers are. It recognizes that firms may take a long run approach when assessing marketplace demand. Marketing concept includes present company capabilities, potential company capability, company objectives, owner aspiration, current and future consumer wants, consumer behavior and market structure (Sharp, 1991).

While a marketing orientation implies that a firm should focus on its customers, an entrepreneurial orientation suggests that organizations must constantly seek to exploit the dynamics of their macro environment and task environments. Thus, an entrepreneurial orientation provides an excellent basis for the appropriate strategic response to organizational crises caused by environmental turbulence (Hill \& Wright, 2000). Entrepreneurial orientation is the propensity of a company's top management to take calculated risks, to be innovative, and to demonstrate proactiveness (Morris \& Paul, 1987). They also suggest that both the marketing orientation and the entrepreneurial orientation are interrelated strategic responses to environmental uncertainty (Miles \& Arnold, 1991).

Research about marketing and entrepreneurial orientation has already implemented in small business (Haryati et al., 2018) (Haryati, Lilavalicakul, \& Surrahman, 2019). Marketing orientation has significant influence to business performance (Ngai, Jimmy, \& Ellis, 1998). There is also a moderating effect between both marketing orientation and entrepreneurial marketing (Becherer \& Maurer, 1998) however there is no research about organizational innovation as intermediary variables. Organizational innovation has relation to business performance. It is enabler the technological innovation capabilities and firm performance (Camisón \& Villar-López, 2014). It is also plays a key role on firm performance and competitiveness (Uzkurt et al., 2013). Based on the background, this aim of the research is to understand whether Indonesian farmers area good managers, and then to understand the relation between marketing orientation and entrepreneurial orientation to farming performance. 


\section{RESEARCH METHOD}

\section{Respondent, data collection and sampling technique}

The method used in this research is descriptive quantitative method. Quantitative method is the process of finding knowledge that uses data in the form of numbers as a tool to analyze information (Silalahi, 2015) while descriptive is the research that data and statements obtained from the results of direct interaction between the researcher and the object under study (Soendari, 2010). A literature review is used to help comprehend the relation between farmers decision and to answer whether they are a good manager or not. The research data used are primary data obtained from interviews with rice farmers, each of which numbered 40 people The sampling technique was purposive, it is the deliberate choice of a participant due to the qualities of the participant possesses (Etikan, 2016).

\section{Data Analysis}

Data collected through a questionnaire then proceed with a 5-level Likert measurement scale. The questionnaire that was filled in by respondents was tested for validity, reliability, and linearity (Beglar \& Nemoto, 2014). Validity Test consists of convergent validity that uses an Average Variance Extracted of 0,5. Discriminant validity is indicated by the AVE value of each latent variable which must be greater than the highest $r 2$ value. Furthermore, the loading value for each indicator is expected to be higher than the cross-loading (Sarwono, 2010). Reliability tests can be performed using the Cronbach's Alpha Alpha method. If the alpha value is $>0,90$ then the reliability is perfect; alpha value of $0,70-0,90$, the high reliability; alpha value $0,50-$ 0,70 then moderate reliability; alpha value $<0,50$, low reliability. While the linearity test criteria are the value of the linearity level is less than 0,05 ( $\mathrm{p}<0,05)$ (Ulum et al., 2014; Sarwono, 2010).

Hypothesis testing is to determine the decision whether to reject or accept the truth of the statement that has been made. Hypothesis testing with a probabilistic approach, in the form of $\mathrm{p}$ values from statistical tests conducted with WarpPLS 6.0 software (Awang, Wan Afthanorhan, $\&$ Asri, 2015). Statistical test decisions are made by comparing p-values with alpha values $(\alpha)$, with the following conditions: If the p-value $<\alpha$ value, the decision $\mathrm{H} 0$ is rejected (H1 accepted). If p-value $>\alpha$ value, the decision $\mathrm{H} 0$ is accepted (H1 is rejected). The $\alpha$-value used is 0,1 or 10 percent. The $\alpha$-value states that the level of accuracy used in this study is equal to 10 percent. Development of research hypotheses as follows:

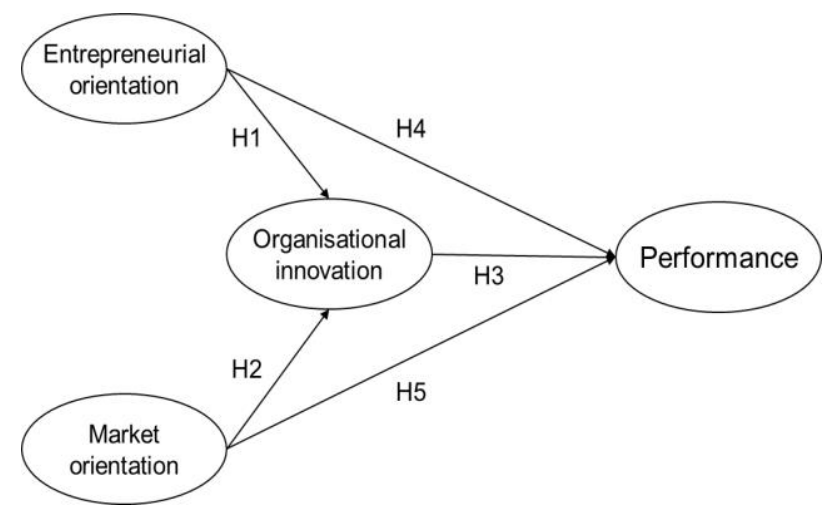

Figure 1. Hypothesis and Model Formulation

Farmers entrepreneurial activity and innovation orientation are necessary to face the complex and multi-faceted environment in which they operate. Innovative entrepreneurial orientation attitude in the farming context to explain the notion of farmers' openness towards new ideas, similar to suggestions by other studies in organizational literature (Gellynck et al., 2014). Entrepreneurial Orientation (EO) has been acknowledged as a determinant for a firm's growth and profitability. High growth would be a result of innovativeness, pro-activeness and risk-taking orientation by the firm, the scopes which refer to an entrepreneurial orientation (EO) 
(Zainol \& Ayadurai, 2011)This leads to a proposal that entrepreneurial orientation has a significant direct effect to farming performance.

$\mathrm{H1}$ : Entrepreneurial orientation (X1) has a significant direct effect to farming performance (Y1)

$\mathrm{H} 4$ : Entrepreneurial orientation (X4) has a significant indirect effect to farming performance (Y1)

An enterprise which is market oriented is the enterprise or business entity which develops a better understanding inside the enterprise itself of customer needs (Pramono et al., 2015). It is able to meet changing consumer needs through adopting new products, services and unique marketing mixtures (Mirzaei, Micheels, \& Boecker, 2016). This leads to a proposal that market orientation has a significant direct effect to farming performance.

$\mathrm{H} 2$ : Market orientation (X2) has a significant indirect effect to farming performance (Y1)

H5: Market orientation (X5) has a significant direct effect to farming performance (Y1)

That training and education might generally be regarded as a means of facilitating farmers to adopt innovations that lift farm productivity and increase farm profitability. In theory, training and education should allow farmers to improve their management by enhancing their decision-making skills (Xayavong, Kingwell, \& Islam, 2016). However, organizations sometimes fail to achieve sustainable competitive advantage due to their limited understanding of the relationships between these strategic variables (García-Morales, Lloréns-Montes, \& Verdú-Jover, 2008). This leads to a proposal that organizational innovation has a significant direct effect to farming performance.

H3: Organisational innovation (X3) has a significant direct effect to farming performance (Y1)

\section{RESULT AND DISCUSSION}

\section{Are they good managers?}

Descriptive method and literature review have shown some research results. Besides this, the question guide is used so that farmers are truly able to answer questions according to the research needs. The concept used is the concept of agribusiness, and continued with the concept of management.

Wet field rice agribusiness that is done in Malang by Farmer's group, is a process of developing local business of agriculture supported by four subsystems of agribusiness, namely: (1) upstream sub-system, through providing infrastructure for production (wet field rice seeds, fertilizer, and pesticide, (2) agribusiness subsystem such as rice field culture (soil management, planting, crops management, harvesting, and post harvesting), (3) downstream sub-system such as processing and handling of the yield (diversification of rice products), and (4) supporting subsystem such as provision of agribusiness capital, either from the financing institutions and marketing facilities and infrastructure (Bahua \& Ikbal, 2016).

Management functions are planning, organizing, implementing, and controlling / evaluating (Pratama et al., 2011) and its application in agriculture has been carried out before to formulate farming development strategies (Roosany et al., 2014). Whereas in this study farming planning carried out by farmers is to determine what plants are cultivated. Organizing carried out by farmers is to prepare production inputs in this case are fertilizers, medicines, and so forth. Some of the problems faced by farmers are difficulties in fulfilling these production inputs due to limited products and expensive prices without subsidies from the government. The implementation is by conducting farming cultivation, however, the monoculture system carried out by farmers continuously can cause the land to be more vulnerable to pests and diseases that have the potential to cause harm. It is too early to say whether they are risk takers or risk averter farmers, but there are many obstacles to be carried out, namely pest attack is considered to ruin the harvest. That is because the attack can cause crop damage before harvest so that it does not get results. Meanwhile, if the production is low, farmers still think that they will get a small yield. Selling prices are not an obstacle because most farmers do not sell their crops. They still carry out subsistence farming. Controlling can be done by looking at indicators of agricultural success. And the 40 farmers agreed that the indicator of farming success was high productivity 
for 3 consecutive growing seasons. However, due to uncertain season changes, they argue that this rarely happens.

\section{Validity, Reliability and Goodness of Fit}

Validity can be seen from the value of cross loading and loading factors in Table 1. While Table 2 shows the value of Average variances extracted which is above the value of 0,5 , and it shows that the research questionnaire is valid.

Table 1. Cross-Loadings and Loading Factors

\begin{tabular}{|c|c|c|c|c|c|}
\hline & $\mathrm{X} 1$ & $\mathrm{X} 2$ & Y1 & $\mathrm{Y} 2$ & $P$ value \\
\hline X1.1 & 0,800 & $-0,392$ & 0,305 & $-0,259$ & $<0,001$ \\
\hline$X 1.2$ & 0,657 & 0,300 & $-0,622$ & 0,083 & $<0,001$ \\
\hline $\mathrm{X} 1.3$ & 0,794 & $-0,213$ & 0,324 & 0,180 & $<0,001$ \\
\hline X 1.4 & 0,902 & 0,048 & 0,286 & 0,039 & $<0,001$ \\
\hline $\mathrm{X} 1.8$ & 0,560 & $-0,025$ & $-0,174$ & 0,409 & $<0,001$ \\
\hline X1.9 & 0,648 & 0,395 & $-0,390$ & $-0,392$ & $<0,001$ \\
\hline $\mathrm{X} 2.1$ & $-0,077$ & 0,757 & 0,622 & 0,161 & $<0,001$ \\
\hline $\mathrm{X} 2.2$ & 0,006 & 0,849 & 0,221 & 0,099 & $<0,001$ \\
\hline$X 2.3$ & $-0,151$ & 0,531 & 0,317 & 0,031 & $<0,001$ \\
\hline$X 2.5$ & 0,104 & 0,802 & $-0,485$ & $-0,086$ & $<0,001$ \\
\hline X2.6 & 0,063 & 0,801 & $-0,548$ & $-0,192$ & $<0,001$ \\
\hline Y 1.1 & $-0,288$ & 0,410 & 0,624 & 0,332 & $<0,001$ \\
\hline Y 1.3 & $-0,380$ & $-0,668$ & 0,635 & 0,395 & $<0,001$ \\
\hline Y1.4 & $-0,342$ & 0,256 & 0,858 & 0,216 & $<0,001$ \\
\hline Y1.5 & 0,370 & $-0,197$ & 0,691 & $-0,532$ & $<0,001$ \\
\hline Y1.6 & 0,341 & $-0,117$ & 0,732 & $-0,243$ & $<0,001$ \\
\hline Y 1.7 & 0,246 & 0,200 & 0,852 & $-0,114$ & $<0,001$ \\
\hline Y 2.1 & $-0,334$ & $-0,609$ & 0,403 & 0,581 & $<0,001$ \\
\hline Y2.2 & 0,607 & $-0,143$ & $-0,179$ & 0,763 & $<0,001$ \\
\hline Y2.3 & $-0,319$ & 0,162 & 0,325 & 0,771 & $<0,001$ \\
\hline $\mathrm{Y} 2.4$ & $-0,301$ & 0,085 & $-0,048$ & 0,781 & $<0,001$ \\
\hline Y2.5 & 0,251 & 0,321 & $-0,367$ & 0,845 & $<0,001$ \\
\hline
\end{tabular}

Source: primary data (processed in 2020)

Table 2. Composite Reliability, Cronbach's Alpha and Average variances extracted

\begin{tabular}{lccc}
\hline Variables & $\begin{array}{c}\text { Composite } \\
\text { Reliability }\end{array}$ & Cronbach's Alpha & AVE \\
\hline Marketing orientation (X1) & 0,874 & 0,824 & 0,541 \\
Entrepreneurial orientation (X2) & 0,867 & 0,806 & 0,572 \\
Organizational innovation (Y1) & 0,876 & 0,827 & 0,545 \\
Farming performances (Y2) & 0,866 & 0,805 & 0,568 \\
\hline
\end{tabular}

Source: primary data (processed in 2020)

While reliability can be seen from Table 2 with the overall Composite Reliability indicator which has reached greater than 0,7 and Cronbach's alpha which is greater than the number 0.6. It can be said that the research questionnaire is reliable. Table 3 shows the Goodness of fit where the 10 indicators have shown good and ideal values, so that it can be continued for hypothesis testing.

Table 3. Model Fit and Quality Indices

\begin{tabular}{llll}
\hline Model Fit and Quality Indices & Fit Criteria & Result \\
\hline Average path coefficient (APC) & $\mathrm{P}<0,05$ & $0,390(\mathrm{p}=0,002)$ & Ideal \\
Average R-Squared (ARS) & $\mathrm{P}<0,05$ & $0,537(\mathrm{p}<0,001)$ & Ideal \\
Average adjusted R-squared (AARS) & $\mathrm{P}<0,05$ & $0,504(\mathrm{p}=<0,001)$ & Ideal \\
Average block VIF (AVIF) & Acceptable if $<=5$, Idealy $<=3.3$ & 1,256 & Ideal \\
Average full collinearity VIF (AFVIF) & Acceptable if $<=5$, Idealy $<=3.3$ & 1,694 & Ideal \\
Tenenhaus GoF (GoF) & Small $>=1$, & 0,547 & Large \\
Sympson's paradox ratio (SPR) & Medium $>=0,25$, Large $>=0,36$ & 0,900 & Good \\
R-Squared contribution ratio (RSCR) & Acceptable if $>=0,7$, Idealy $=1$ & 1,000 & Good \\
Statistical suppression ratio (SSR) & Acceptable if $>=0,9$, Idealy $=1$ & 0,900 & Acceptable if $>=0,7$ \\
Nonlinear bivariate causality direction ratio & Acceptable if $>=0,7$ & & Good \\
(NLBCDR) & & &
\end{tabular}


Effect of Market orientation and Entrepreneurial Orientation to Farming Performance

Figure 2 shows the relationship between latent variables to farming performance (Y2).

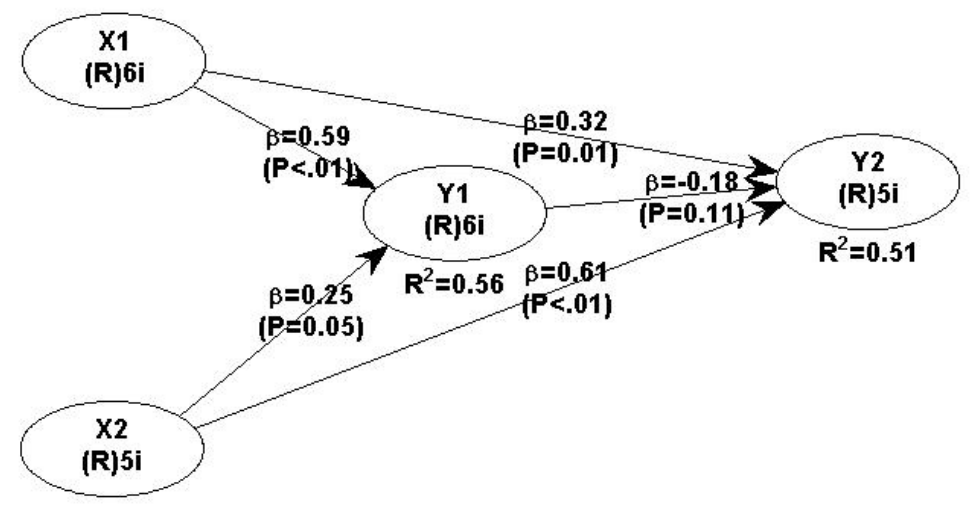

Figure 2. Research Result

In general, effects or effects can be divided into direct effects, indirect effects, and total effects The direct effect between two latent variables occurs when there is an arrow connecting the two variables, where this effect is measured by the estimated value between variables. Influence no directly between the two variables can occur when a variables affect other variables by going through one or more variables latent in accordance with the path contained in the research model (Sarwono, 2010). Table 4 shows direct, indirect and total effect.

Table 4. Hypothesis Testing

\begin{tabular}{llll}
\hline & Direct Effect & Indirect effect & Total Effect \\
\hline $\mathrm{X} 1$-> Y1 & $0,59(\mathrm{p}<0,01)^{*}$ & - & 0,592 \\
$\mathrm{X} 2$ - Y 1 & $0,25(\mathrm{p}=0,05)^{* *}$ & - & 0,249 \\
$\mathrm{Y} 1$-> Y2 & $-0,18(\mathrm{p}=0,11)^{* * *}$ & - & $-0,183$ \\
$\mathrm{X} 1$-> Y2 & $0,32(\mathrm{p}=0,01)^{* *}$ & - & 0,32 \\
$\mathrm{X} 2$-> Y2 & $0,61(\mathrm{p}<0,01)^{*}$ & - & 0,61 \\
$\mathrm{X} 1->\mathrm{Y} 1$-> Y2 & 0,59 & $-0,18$ & 0,41 \\
$\mathrm{X} 2$-> Y1 -> Y2 & 0,25 & $-0,18$ & 0,07 \\
\hline Note: * highly significant; ** significant; ***weakly significant &
\end{tabular}

Note: * highly significant; ** significant; ***weakly significant

\section{Effect of Marketing and Entrepreneurship orientation on organizational innovation}

Marketing orientation has positive direct effect to the organizational innovation with the value of 0,59 with $p$ value of $>0,01$. Some research has support this result, this means that marketing orientation has significant effect to organizational innovation (Carmen \& José 2008; Fonseca \& Baptista 2013; Han, Kim, \& Srivastava 1998; Hurley et al., 1998). Thus, H1 can be accepted. Entrepreneurship orientation has positive and direct effect to organizational innovation with the value of 0,25 with $\mathrm{p}$ value of $>0,01$ (highly significant). This highly significant shows that some factors can be seen in loading factors are highly significant to organizational innovation (Abdullah Kaid Al-Swidi, 2012; Farsi, Rezazadeh, \& Najmabadi, 2014). Thus, $\mathrm{H} 2$ can be accepted.

\section{Effect of marketing and entrepreneurship orientation on farm performance}

The direct effect of marketing (X1) and entrepreneurship orientation (X2) on farming performance (Y2) is 0,32 and 0,61 . The relationship between marketing orientation is significant while entrepreneurial marketing is very significant on farming performance (Gellynck et al., 2014; Grande, Madsen, \& Borch, 2011; Veidal \& Flaten, 2014). Meanwhile, the indirect effect of the two is 0.41 for marketing orientation towards farming performance, while entrepreneurial orientation towards farming performance is worth 0.07 with a significant value. Thus, $\mathrm{H} 4$ and $\mathrm{H} 5$ can be accepted. Organization innovation is an intervening or mediating variable. 


\section{CONCLUSION}

Indonesian farmers understand the important of having entrepreneurial and marketing orientation. Both, Marketing orientation and Entrepreneurial orientation have a very significant effect on farming performance on rice farming. Organizational innovation doesn't give better effect on both of latent variable and this means that training and education did not yet allow farmers to improve their management by enhancing their decision-making skills. Future studies need to look deeper into the relationship of organizational innovation to performance, for example in other commodities, because in this variable there are many important innovations in farming.

\section{REFERENCES}

Abdullah Kaid Al-Swidi. (2012). Total quality management, entrepreneurial orientation and organizational performance: The role of organizational culture. African Journal of Business Management, 6(13), 4717-4727.

Aldillah, R. (2016). Kinerja Pemanfaatan Mekanisasi Pertanian dan Implikasinya dalam Upaya Percepatan Produksi Pangan di Indonesia. Forum Penelitian Agro Ekonomi, 34(2), 163.

Awang, Z., Wan Afthanorhan, W. M. A., \& Asri, M. A. M. (2015). Parametric and Non Parametric Approach in Structural Equation Modeling (SEM): The Application of Bootstrapping. Modern Applied Science, 9(9), 58-67.

Bahua, \& Ikbal, M. (2016). Assessing Professional Competencies of Agricultural Extension Workers : A Case Study of Indonesian's Agribusiness Sector, (2), 13-18.

Becherer, R. C., \& Maurer, J. G. (1998). The proactive personality disposition and entrepreneurial behavior among small company presidents. Journal of Small Business Management, 37(1): 28-36.

Beglar, D., \& Nemoto, T. (2014). Developing Likert-scale questionnaires. JALT2013 Conference Proceedings, 1-8.

Buskop, W. (2010). (12) Ulllted States Patent ( 45 ) Date of Patent : 1(12), 2-5.

Camisón, C., \& Villar-López, A. (2014). Organizational innovation as an enabler of technological innovation capabilities and firm performance. Journal of Business Research, 67(1), 2891-2902.

Carmen, C., \& José, G. M. (2008). The role of technological and organizational innovation in the relation between market orientation and performance in cultural organizations. European Journal of Innovation Management, 11(3), 413-434.

Daryanto, A. (2009). Position of Agriculture Competitiveness in Indonesia and Its Efforts for Improvement. Jurnal Manajemen dan Agribisnis (1), 34-39.

Etikan, I. (2016). Comparison of Convenience Sampling and Purposive Sampling. American Journal of Theoretical and Applied Statistics, 5(1), 1.

Farsi, J. Y., Rezazadeh, A., \& Najmabadi, A. D. (2014). Social Capital and Organizational Innovation: The Mediating Effect of Entrepreneurial Orientation. SSRN Electronic Journal, 2, 22-40.

Fonseca, S., \& Baptista, A. (2013). Market orientation, organizational learning, innovation and performance: keys to the sustainability of non-profits. In European Scientific Journal, (16), 259-264.

García-Morales, V. J., Lloréns-Montes, F. J., \& Verdú-Jover, A. J. (2008). The effects of transformational leadership on organizational performance through knowledge and innovation. British Journal of Management, 19(4), 299-319.

Gellynck, X., Cardenas, J., Pieniak, Z., \& Verbeke, W. (2014). Association between Innovative Entrepreneurial Orientation, Absorbtive Capacity and Farm Business Performance. Agribusiness: An International Journal, 0(0), 1-16.

Grande, J., Madsen, E. L., \& Borch, O. J. (2011). The relationship between resources, entrepreneurial orientation and performance in farm-based ventures. Entrepreneurship and Regional Development, 23(3-4), 89-111. 
Guohua, S. (2013). Research on the fresh agricultural product supply chain coordination with supply disruptions. Discrete Dynamics in Nature and Society.

Han, J. K., Kim, N., \& Srivastava, R. K. (1998). Market orientation and organizational performance: Is innovation a missing link? Journal of Marketing, 62(4), 30-45.

Haryati, N., Lilavalicakul, A., \& Surrahman, M. A. (2019). Can Small and Medium Enterprises Survive in MEA 2025: A Case Study of Agro-industry SMEs in Indonesia. Asia Pacific Management and Business Application, 008(01), 1-10.

Haryati, N., Surahman, M. A., Kurniawan, M., \& Amalia, F. (2018). Entrepreneurial marketing strategy on tempe sanan chips small and medium entreprises in Malang. Advances in Food Science, Sustainable Agriculture and Agroindustrial Engineering, 1(2), 34-39.

Hill, J., \& Wright, L. T. (2000). Defining the Scope of Entrepreneurial Marketing: a Qualitative Approach. Journal of Enterprising Culture, 08(01), 23-46.

Holloway, L., Cox, R., Venn, L., Kneafsey, M., Dowler, E., \& Tuomainen, H. (2006). Managing sustainable farmed landscape through "alternative" food networks: A case study from Italy. Geographical Journal, 172(3), 219-229.

Hurley, R. F., Hult, G. T. M., Abrahamson, E., \& Maxwell, S. (1998). Innovation, Learning: An Organizational and Empirical Integration Examination. Journal of Marketing, 62(3), $42-54$.

Kallen, R., Morse, K., Grosse, D., \& Leonard, D. (2001). Small-Scale Oyster Farming for Chesapeake Watermen A Sustainable Business Marketing Plan. Science, September, 31.

Kasryno, F. (2016). Sumber Daya Manusia dan Pengelolaan Lahan Pertanian di Pedesaan Indonesia. Forum Penelitian Agro Ekonomi, 18(1-2), 25.

Miles, M. P., \& Arnold, D. R. (1991). The Relationship between Marketing Orientation and Entrepreneurial Orientation. Entrepreneurship Theory and Practice, 15(4), 49-66.

Mirzaei, O., Micheels, E. T., \& Boecker, A. (2016). Product and marketing innovation in farmbased businesses: The role of entrepreneurial orientation and market orientation. International Food and Agribusiness Management Review, 19(2), 99-130.

Morris, M. H., \& Paul, G. W. (1987). The relationship between entrepreneurship and marketing in established firms. Journal of Business Venturing, 2(3), 247-259. https://doi.org/10.1016/0883-9026(87)90012-7

Nell, W. T., \& Napier, R. J. (2005). Strategic Approach To Farming Success. 383-388.

Ngai, C. H., Jimmy, \& Ellis, P. (1998). Market orientation and business performance: Some evidence from Hong Kong. International Marketing Review, 15(2), 119-139.

Okello, J. J., \& Mensah, E. R. (2011). Factors Influencing Awareness and Use of Electronic Based Market Information Services for Farming Business in Malawi. International Journal of Economics and Research, 02(04), 43-58.

Okorley, E. L., Acheampong, L., \& Abenor, M. T. E. (2014). The current status of mango farming business in Ghana: A case study of mango farming in the Dangme West District. Ghana Journal of Agricultural Science, 47(1), 73-80.

Pramono, R. B., Nimran, U., Kertahadi, \& Utami, H. N. (2015). The Influence of Market Orientation and Learning Orientation on Performance through Competitive Advantage: An Empirical Study on Combined Farmer Groups of the Tidal Area in South Sumatera Province. European Journal of Business and Management, 7(9), 232-240.

Pratama, R. Y., Jenderal, U., \& Yani, A. (2011). Fungsi-Fungsi Manajemen. Jakarta: PT. Gramedia.

Roosany, T. I. N., Setiawan, I. G., Putra, A., \& Astiti, N. W. S. (2014). Strategi Pengembangan Usaha Sayur Organik pada CV Golden Leaf Farm Bali Strategy of Organic Vegetable Development at CV Golden Leaf Farm Bali Pendahuluan. Jurnal Manajemen Agribisnis (Journal Of Agribusiness Management), 2(1), 61-75.

Sarwono, Y. (2010). Pengertian Dasar Structural Equation Modeling (SEM). Jurnal Ilmiah Manajemen Bisnis Ukrida, 10(3), 98528.

Sharp, B. (1991). Erratum. International Journal of Wine Marketing, 3(1), 20-25. 
Silalahi, U. (2015). Metode Penelitian Sosial Kuantitatif. Journal of Visual Languages \& Computing, 11(3), 287-301.

Soendari, T. (2010). Metode Penelitian Deskriptif, 1-25. Jakarta: PT. Gramedia

Suess-Reyes, J., \& Fuetsch, E. (2016). The future of family farming: A literature review on innovative, sustainable and succession-oriented strategies. Journal of Rural Studies, 47, $117-140$.

Ulum, M., Tirta, I. M., Anggraeni, D., \& . (2014). Structural Equation Modeling Analysis For Small Samples With Partial Least Square Approach [Analisis Structural Equation Modeling Untuk Sampel Kecil Dengan Pendekatan Partial Least Square]. Prosiding Seminar Nasional Matematika Universitas Jember, 1(1), 1-15.

Uzkurt, C., Kumar, R., Kimzan, H. S., \& Eminoğlu, G. (2013). Role of innovation in the relationship between organizational culture and firm performance: A study of the banking sector in Turkey. European Journal of Innovation Management, 16(1), 92-117.

Veidal, A., \& Flaten, O. (2014). Entrepreneurial orientation and farm business performance: The moderating role of on-farm diversification and location. International Journal of Entrepreneurship and Innovation, 15(2), 101-112.

Xayavong, V., Kingwell, R., \& Islam, N. (2016). How training and innovation link to farm performance: A structural equation analysis. Australian Journal of Agricultural and Resource Economics, 60(2), 227-242.

Zainol, F. A., \& Ayadurai, S. (2011). Entrepreneurial Orientation And Firm Performance: The Role Of Personality Traits In Malay Family Firms In Malaysia. International Journal of Business and Social Science, 2(1), 13. 